\title{
Optimization of the Solid Waste Management System in Saint-Petersburg Based on the Morphological Composition Study
}

\author{
Alexander Chusov ${ }^{1}$, Ekaterina Neguliaeva ${ }^{1}$, and Mikhail Romanov ${ }^{1, *}$ \\ ${ }^{1}$ Peter the Great St.Petersburg Polytechnic University, Polytechnicheskaya, 29, St. Petersburg, \\ 195251, Russia
}

\begin{abstract}
The article presents the results of research (2013-2017) on the seasonal morphological composition of Municipal Solid Waste and forecasting the waste generation volume for Saint Petersburg. The authors propose ways to improve the system of solid waste management in St. Petersburg based on these researches.
\end{abstract}

\section{Introduction}

The annual generation of Municipal Solid Waste (MSW) in the Russian Federation is estimated about 120 million $\mathrm{m}^{3} ; 12.5$ million $\mathrm{m}^{3}$ of which are accounted for Northwestern Federal District, 6 million $\mathrm{m}^{3}$ being accounted for Saint Petersburg only [1,2].

The main objectives of waste management in Russia are as follows [2-3]:

a) maximum use of selective MSW collection to produce secondary resources and reduce the volume of waste to be neutralized;

b) optimum MSW landfills management with the subsequent land rehabilitation;

c) construction of highly-mechanized complex waste treatment facilities.

Domestic and foreign experience shows that over time there are significant changes in the composition and properties of waste [4-8].Thus, an effective solution to the abovementioned challenges is problematic without appropriate information on MSW generation volume and morphological composition. It should also be emphasized here that MSW generation volume is difficult to forecast, due to its high dependence on economic, climatic and social factors (Beigl et al., 2008; Denafas et al., 2014; Jalili and Noori, 2008; Lihachev et al., 2006; Lindh, 2003) [6, 9, 10-12].

Conducted studies were aimed at clarifying MSW generation volume and its morphological composition in order to develop practical recommendations to improve the existing waste management system.

\footnotetext{
${ }^{*}$ Corresponding author: rom@spbstu.ru
} 


\section{Forecasting waste generation volume and study of MSW morphological composition in Saint-Petersburg. Material and methods}

The mathematical model, used for forecasting MSW generation volume, is described in the research in detail $[13,14]$. The model takes into account such factors as population, gross domestic product (per capita), average relative humidity (\%) and average air temperature $\left({ }^{\circ} \mathrm{C}\right)$.

Model calculations have shown that MSW volumes in Saint Petersburg will have grown up to 12.1 million $\mathrm{m}^{3}$ (1838 thousand tons) by 2017 and 13.4 million $\mathrm{m}^{3}$ (2037 thousand tons) by 2020. It is evident that the existing city facilities are not sufficient for disposal of such waste volumes.

At present, most municipal waste is collected into the standard containers of a varied capacity $\left(0.75 / 6 / 12 \mathrm{~m}^{3}\right)$. "Containerless collection" of MSW is mainly used in suburban areas and neighborhoods of a longstanding dense housing. It should also be noted, that up to $40 \%$ of houses built in $1950-1980$ are equipped with the garbage chute [2, 10, 15]. Methods and techniques of MSW collection and disposal being; applied result in the formation of MSW flows with significant diversity in the primary content.

Another important factor affecting the morphological composition of MSW, which is delivered to disposal and processing facilities, is a varied degree of prior secondary raw materials extraction from MSW. St. Petersburg transport companies rely on two-stage MSW transportation process: reloading MSW from containers, the waste was initially collected to from the apartment buildings owners, into containers of a larger capacity (generally from 6 $\mathrm{m}^{3}$ into $27 \mathrm{~m}^{3}$ ). The main reason for this procedure is reduction in transportation costs through MSW consolidation and reloading into large capacity containers for heavy garbage trucks.

Such two-stage transportation process contributes to prior secondary raw materials extraction, which adversely affects the cost-effectiveness of MSW treatment and further processing.

Average MSW morphological composition in St. Petersburg in 2000 [16] is presented in the Table 1.

The transfer station, maintained by specialized municipal company "Spetstrans 1" "Predportovaya", was selected as a site for research purposes in 2013-2016. The station output is 2.5 thousand $\mathrm{m}^{3} /$ day; the following areas are covered - Moscovskiy, Kirovskiy, Frunzenskiy districts of Saint Petersburg.

Covered areas are quite representative in terms of urban development indicators, MSW collection and disposal schemes and selective collection of scrap practices.

Research site selection was justified by volumes of incoming MSW, representative characteristics of the waste collection area, as well as the technical capacity for site screening analysis preparations.

The existing approaches of study MSW seasonal variations are slightly different. In order to unify the methodology and common approaches the following guidelines have been developed: «Methodology for Determination of the Composition of Unprocessed Municipal Solid Waste and Waste Composition Dependence from Regional Social-Economic and Climate Characteristics». This methodology is based on standard methods listed below: Standard Test Methods for MSW Determination (LST CEN/ISO 14780 «Solid biofuels Method for sample preparation»; ASTM D 5231 - 92 «Standard Test Method for Determination of the Composition of Unprocessed MSW»; ASTM D 4687 - 95 «Standard Guide for General Planning of Waste Sampling»).

The main requirement in the study of MSW composition was the provision of the primary sample representativeness, since the composition of the analytical sample must strictly comply with the average composition of the full volume of the investigated waste. 
Table 1. Average morphological composition of MSW in St. Petersburg in 2000.

\begin{tabular}{|c|c|c|}
\hline № & Component & Quantity, \% \\
\hline 1 & Waste paper (cardboard, paper) & 15.6 \\
\hline 2 & Food waste & 34.9 \\
\hline 3 & Waste plastics & 11.3 \\
\hline 4 & Black metals & 4.4 \\
\hline 5 & Non-ferrous metals & 0.2 \\
\hline 6 & Glass & 13.7 \\
\hline 7 & Textile & 3.8 \\
\hline 8 & Wood & 0.8 \\
\hline 9 & Leather, rubber & 1.0 \\
\hline 10 & Rock & 3.0 \\
\hline 11 & Bone & 1.6 \\
\hline 12 & Other & 9.7 \\
\hline 13 & In total & 100.0 \\
\hline
\end{tabular}

\section{Results and discussion}

The results of experimental studies are presented in the Table 2.

The largest volume of MSW was generated in autumn with maximum in October $(32 \mathrm{~kg}$ per capita), and the smallest volume in summer with minimum in June (18 kg per capita). Seasonal variations of total waste volume are mainly due to city population changing in summer and increase in waste amount due to cleaning of yards and roads in autumn and spring.

Major share of MSW accounts for paper wastes (maximum $25.6 \%$ in February), plastic (maximum $19.9 \%$ in December), and glass (maximum $11.2 \%$ ). Food wastes share reached minimum in February (1.4\%) and maximum in June (15.4\%). Large volume of waste was considered as under-sieve fraction. This fraction is less than $8 \mathrm{~cm}$ consisting of a mixture of 
dust, sweepings, gravel, food wastes, plastic and paper particles that could not be sorted manually.

Table 2. Morphological composition of MSW [\%] in St. Petersburg for 2016, by month.

\begin{tabular}{|c|c|c|c|c|c|c|c|}
\hline Component & January & February & March & April & May & June & July \\
\hline Wastepaper & 20.1 & 25.6 & 21.1 & 19.0 & 18.1 & 14.8 & 14.4 \\
\hline Glass & 7.6 & 7.9 & 7.5 & 7.6 & 9.1 & 7.3 & 11.2 \\
\hline Polymers & 19.1 & 19.6 & 18.1 & 18.0 & 15.7 & 14.3 & 14.8 \\
\hline Textile & 3.1 & 3.0 & 3.1 & 3.3 & 3.5 & 3.5 & 3.3 \\
\hline Metals & 3.6 & 3.7 & 3.1 & 3.8 & 3.0 & 2.2 & 2.8 \\
\hline Food waste & 1.7 & 1.4 & 2.1 & 2.5 & 5.6 & 8.2 & 15.4 \\
\hline Other & 7.2 & 7.4 & 8.2 & 7.1 & 7.3 & 7.4 & 7.8 \\
\hline $\begin{array}{c}\text { Under-sieve } \\
\text { fraction }\end{array}$ & 37.6 & 31.6 & 36.7 & 38.6 & 37.8 & 42.3 & 30.4 \\
\hline Total & 100.0 & 100.0 & 100.0 & 100.0 & 100.0 & 100.0 & 100.0 \\
\hline
\end{tabular}

Table 2. Morphological composition of MSW [\%] in St. Petersburg for 2016, by month (cont.)

\begin{tabular}{|c|c|c|c|c|c|c|}
\hline Component & August & September & October & November & December & Average \\
\hline Wastepaper & 15.7 & 10.5 & 17.4 & 21.1 & 18.4 & 18.0 \\
\hline Glass & 10.0 & 9.4 & 8.7 & 9.5 & 9.0 & 8.7 \\
\hline Polymers & 13.5 & 13.4 & 16.4 & 16.9 & 19.9 & 16.6 \\
\hline Textile & 3.1 & 3.4 & 3.3 & 3.1 & 3.1 & 3.2 \\
\hline Metals & 2.3 & 1.9 & 2.1 & 2.4 & 3.3 & 2.8 \\
\hline Food waste & 10.3 & 10.9 & 8.0 & 3.8 & 3.6 & 6.1 \\
\hline $\begin{array}{c}\text { Other } \\
\text { fraction }\end{array}$ & 7.9 & 7.8 & 7.6 & 7.5 & 7.6 & 7.6 \\
\hline $\begin{array}{c}\text { Total } \\
\text { fnder-sieve }\end{array}$ & 100.0 & 100.0 & 100.0 & 100.0 & 100.0 & 100.0 \\
\hline
\end{tabular}

An analysis of MSW composition in the past 16 years indicates that amount of glass has increased twofold, polymer waste - by half, paper and cardboard - by 1.4 times. At the same time wood waste decreased twofold, ferrous metal waste - by $20 \%$ and non-ferrous metals waste - by 5 times. 
Fractional composition of waste components plays a decisive role in the following: collection and transportation methods; developing parameters of machinery and equipment (crushers, compactors, screens) for waste disposal facilities construction; waste recycling technology and methods; as well as, determines their characterization as a source of the secondary raw material.

The fractions and sub-fractions were categorized according to treatment feasibility and classical waste management hierarchy: recycling, composting, incineration and landfilling. We considered the main share of paper and plastics as well as metals, tetra-packs and glass to be recycled, food and yard waste - composted, lower share of paper and plastics, wood and other organic would be incinerated with energy recovering, and only other inorganic waste would be landfilled (Tab. 3). The hazardous waste was neglected due to its minor content in the composition. Furthermore, the correlations between generation of these fractions and total MSW generation have been determined.

Table 3. Categorization of MSW fractions and sub-fractions according to treatment feasibility.

\begin{tabular}{|c|c|}
\hline Treatment feasibility & Fractions and sub-fractions \\
\hline Recyclable & $\begin{array}{r}\text { Newspaper, glossy paper, office paper, cardboard, PET, } \\
\text { HDPE, films, PS, tetrapacks, metals, glass }\end{array}$ \\
\hline Compostable & Food waste, yard waste \\
\hline Incinerable & Mixed paper, other plastics, wood, other organic \\
\hline Landfilled & Other inorganic waste \\
\hline
\end{tabular}

Determined generation of MSW grouped fractions in accordance with different treatment feasibilities.

Figure 1 illustrates the results of MSW categorized fractions generated in accordance with different treatment feasibilities.

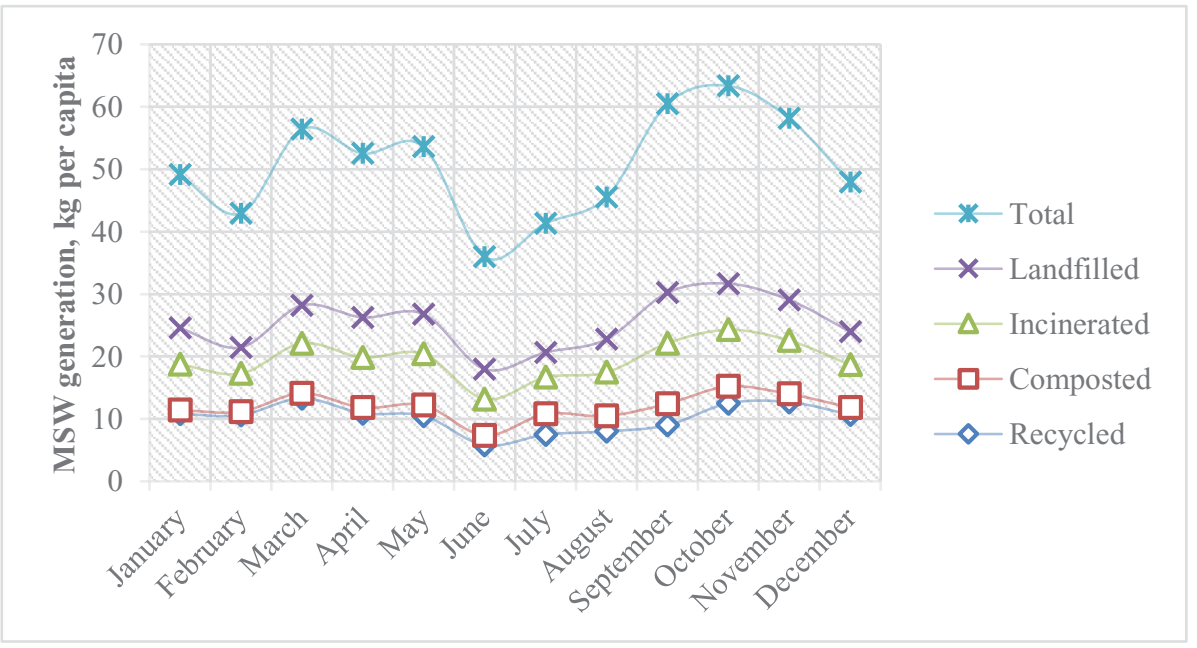

Fig. 1. Monthly generation of MSW categorized fractions, kg per capita, Saint Petersburg, 2016.

Figure 1 indicates that $70-75 \%$ of the MSW generated in Saint Petersburg, potentially may be recycled into marketable products. Such processing is the most lucrative method of waste management, as it eliminates the need to find new areas for landfills construction, and 
allows to monitor the status of waste (in the case of landfill). It also solves problems, related to the utilization of toxic ash and slag (in the case of waste incineration). Moreover, MSW processing significantly reduces costs associated with the waste disposal by means of selling marketable products. It is noteworthy that processing of selected individual components may even become profitable.

The major problem hindering the processing of the overall volume of the potential secondary resources is the combined collection and transportation of all three groups of MSW, as one group may adversely affect the quality of the other. For instance, paper becomes contaminated by food wastes; biodegradable potential secondary resources become contaminated by plastic and toxic waste.

Results acquired by the authors were used to develop practical recommendations to improve the existing MSW management system in St. Petersburg.

Currently, only a small volume of MSW, generated in St. Petersburg, is processed at two sites of the specialized waste recycling plant, the major amount of MSW is stored at the landfills without processing [2].

As per initial plan, those waste recycling plants focused on recycling biodegradable fragment of MSW into compost suitable for use in agriculture, trough biothermal composting in rotating drums. However, due to the lack of separate food waste collection, generated organic fraction is supplied to recycling plants in the overall MSW composition, together with such high-hazard class components as mercury, lead, etc. [8, 10, 17]. Therefore, the resulting compost is contaminated with heavy metals and is not permitted by sanitary services for agricultural use. As a result, the compost produced in those waste recycling plants has quite limited sales potential (not more than $35 \%$ of the total production volume), and thus is buried at landfills.

Currently mechanisms of state control over the activities in the field of municipal solid waste management are being developed in St. Petersburg, in particular, accounting and monitoring MSW transportation from the formation and/or collection spots to processing, recycling and disposal places.

Complex plants, ensuring the use of waste as a source of energy and as secondary raw materials, are deemed to be the most applicable option for megacities [16, 18, 19]. Industrial technology development based on the combination of different MSW processing methods, taking into account seasonal changes in the MSW morphological composition etc. eliminates potential disadvantages of each individual method. Analysis of the data obtained during the research indicated that this complex MSW processing ensures resource efficiency, combined with maximum environmental and economic feasibility.

Analysis of possible scenarios of waste management industry development on the whole, as well as MSW processing schemes in St. Petersburg, in particular, suggests the following undertakings:

1) Existing MSW landfills, including illegal dumps should be closed and the land should be rehabilitated. "Novoselki" landfill should be equipped with degassing station.

Two new waste recycling plants are to be constructed, while two existing ones are to be modernized to meet St. Petersburg needs in recycling capacity by 2020 . It is proposed to conditionally divide St. Petersburg into four processing zones, taking into account changes in population density and volume of MSW generation. MSW collected in each of the four zones is to be directed to one of the corresponding waste recycling plants for processing.

2) Before putting to operation those waste recycling plants it is advisable to sort MSW at existing waste sorting complexes, increasing the processing depth to a value of at least $20 \%$ by means of modern technological equipment.

3) Compost production in the long term is not considered feasible. The following technologies are recommended to be introduced in St. Petersburg: 
- production of alternative fuels from waste (Solid Recovered Fuel) with ample opportunities to regulate its characteristics in order to meet the needs of a particular customer;

- disposal of MSW and waste of health care institutions with the use of plasma gasification technology (pilot project capacity of 10 thousand tons per year).

Positive energy balance of waste processing plants could cover not only plants' own energy needs, but also ensure the development of adjacent areas by energy-intensive industries localization in those ones [20].

4) In order to implement the MSW collection and disposal based on a single, centralized waste management system, it is necessary to synchronize the overall plan of waste collection and disposal in St. Petersburg with general territory cleaning and waste management plan.

To ensure the efficient functioning of a single, centralized waste management system, a number of organizational measures are proposed:

- regular surveys are recommended in order to verify the actual data on the volume of MSW generation, density, changes in the morphological composition and other quantitative and qualitative characteristics;

- transition from two-stage transportation process to one-stage transportation process of generated MSW due to the centralization of processing at large waste processing plants.

\section{Conclusions}

1. An analysis of MSW composition, carried out in Saint Petersburg in 2013-2017, indicates that amount of glass has increased by 2 times, polymer waste - by 1.5 times, paper and cardboard - by 1.4 times. At the same time wood waste decreased by 2 times, ferrous metal waste - by $20 \%$ and non-ferrous metals waste - by 5 times.

2. Model calculations have shown that MSW volumes in Saint Petersburg will have grown up to 12.1 million $\mathrm{m}^{3}$ (1838 thousand tons) by 2017 and 13.4 million $\mathrm{m}^{3}$ (2037 thousand tons) by 2020 .

3. The research results were used in the development of the Regional target programme of municipal solid and industrial waste management in St. Petersburg for the period of 20122020.

\section{References}

1. G. Denafas, C. Ludwig, A. Chusov, M. Romanov, Yu. Lednova et al., Tverdye bytovye otkhody, 2(92), 39-43 (2014).

2. E.G. Semin, K.N. Tsirikova, S.K. Ovchinnikova, S.Yu. Gorbatova, A.A. Tsibinigin, Biosfera, 6 (1), 29-35 (2014).

3. M.P. Fedorov, Izvestiya Rossiyskoy Akademii nauk: Energetika, 6, 3-4 (2002).

4. P. Beigl, G. Wassermann, F. Schneider, S. Salhofer, IEMSs International Congress «Complexity and Integrated Resources Management», Forecasting Municipal Solid Waste Generation in Major European Cities (2004). Available at: http://www.iemss.org/iemss2004/pdf/regional/beigfore.pdf, accessed 02.07.2018.

5. S. Leao, I. Bishop, D. Evans, Resour. Conserv. Recy., 33(4), 289-313 (2001).

6. Yu.M. Lihachev, V.S. Artamonov, M.Ya. Fedashko, E.G. Semin, G.V. Kozlov, Regional'naya ekologiya, 1-2, 109-112 (2006).

7. M.G. Ryzhakova, V.I. Maslikov, Construction of Unique Buildings and Structures, 8(23), 48-66 (2014).

8. M. Ryzhakova, V. Maslikov, A. Chusov, V. Korablev, Applied Mechanics and Materials, 675-677, 761-769 (2014). 
9. P. Beigl, S. Lebersorger, S. Salhofer, Waste Manage., 28(1), 200-214 (2008).

10. G. Denafas, C. Ludwig, A. Chusov, M. Romanov, E. Neguliaeva et al., Resour. Conserv. Recy., 89, 22-30 (2014).

11. M. Jalili Ghazi Zade, R. Noori, Int. J. Environ. R., 2(1), 13-22 (2008).

12. T. Lindh, Futures, 35, 37-48 (2003).

13. I. Rimaityte, T. Ruzgas, G. Denafas et al., Waste Manage. Res., 30(1), 89-98 (2012).

14. I. Valaviciene The Impact of Seasonal Variations of Municipal Waste Generation on Waste Management System Indicators. Summary of Doctoral Dissertation Technological Sciences, Environmental Engineering, Kaunas University of Technology, 1-35 (2012).

15. S. Vasiutina, N. Vatin, Applied Mechanics and Materials, 633-634, 1018-1022 (2014).

16. E.G. Semin, Yu. M. Lihachev, Zhizn' i bezopasnost', 1-2, 21-22 (2000).

17. E.G. Tihomirova, E.G. Semin, Vestnik Rossiyskogo universiteta druzhby narodov. Seriya: Ekologiya i bezopasnost' zhiznedeyatel'nosti, 1, 82-87 (2010).

18. V.G. Sister, A.N. Mirnii, Tverdye bytovye otkhody, 1, 16-21 (2009).

19. A.V. Marova, A.N. Chusov, E.Yu. Neguliaeva, Tverdye bytovye otkhody, 3, 10-13 (2007).

20. O. Gamayunova, N. Vatin, Applied Mechanics and Materials, 725-726, 1493-1498 (2015). 